\title{
Distribution of Viviparous American Fish Species in Eastern Europe on the Example of Gambusia holbrooki Girarg, 1859 and Poecilia reticulata Peters, 1859 in the Context of Global Climate Change ${ }^{+}$
}

\author{
Oksana Nekrasova ${ }^{1}{ }^{1}$, Volodymyr Tytar ${ }^{1}$, Mihails Pupins ${ }^{2}$, Andris Čeirāns ${ }^{2}$, Oleksii Marushchak ${ }^{1, *}$ and
} Arturs Skute ${ }^{2}$

1 I. I. Schmalhausen Institute of Zoology, National Academy of Sciences of Ukraine, 01030 Kyiv, Ukraine; oneks22@gmail.com (O.N.); vtytar@gmail.com (V.T.)

2 Department of Ecology, Institute of Life Sciences and Technologies, Daugavpils University, LV5400 Daugavpils, Latvia; mihails.pupins@gmail.com (M.P.); andris.ceirans@lu.lv (A.Č.); arturs.skute@du.lv (A.S.)

* Correspondence: ecopelobates@gmail.com; Tel.: +38-096-488-2670

+ Presented at the 1st International Electronic Conference on Biological Diversity, Ecology and Evolution, 15-31 March 2021; Available online: https:/ / bdee2021.sciforum.net/.

check for updates

Citation: Nekrasova, O.; Tytar, V.; Pupins, M.; Čeirāns, A.; Marushchak, O.; Skute, A. Distribution of Viviparous American Fish Species in Eastern Europe on the Example of Gambusia holbrooki Girarg, 1859 and Poecilia reticulata Peters, 1859 in the Context of Global Climate Change. Biol. Life Sci. Forum 2021, 2, 9. https: / doi.org/10.3390/BDEE202109398

Academic Editor: Matthieu Chauvat

Published: 11 March 2021

Publisher's Note: MDPI stays neutral with regard to jurisdictional claims in published maps and institutional affiliations.

Copyright: (c) 2021 by the authors. Licensee MDPI, Basel, Switzerland. This article is an open access article distributed under the terms and conditions of the Creative Commons Attribution (CC BY) license (https:// creativecommons.org/licenses/by/ $4.0 /)$.

\begin{abstract}
The potential distribution of tropical fish species in Eastern Europe-Gambusia holbrooki Girarg, 1859 (introduced for biological control) and Poecilia reticulata Peters, 1859 (aquarium species, found in wastewaters of big cities) — tends to be of particular interest in terms of global climate change. After GIS modeling of our own data and findings listed in the GBIF databases (2278 points for G. holbrooki and 1410 points for P. reticulata) by using the Maxent package and 18 uncorrelated variables of 35 Bioclim climatic parameters from the CliMond dataset, it was found that by 2090, guppies will appear in the south of Ukraine (Danube River estuary, as well as in several places in the Caucasus and Turkey with habitat suitability of $>0.3-0.5)$. G. holbrooki will also slightly expand its range in Europe. Limiting factors for G. holbrooki distribution are as follows: bio1 (annual mean temperature, optimum $+12-+23{ }^{\circ} \mathrm{C}$ ) and bio19 (precipitation of coldest quarter $(\mathrm{mm})$ ). Limiting factors for guppies are as follows: bio1 (optimum $+14-+28^{\circ} \mathrm{C}$ ), bio4 (temperature seasonality), and bio3 (isothermality). Guppies, unlike G. holbrooki, prefer warmer waters (correlation 0.02). Such thermophilic fish species do not compete with the native ichthyofauna, but they can occupy niches in anthropogenically transformed habitats, playing an important role as agents of biological control.
\end{abstract}

Keywords: GIS; modeling; distribution; Gambusia holbrooki; guppies; mosquitofish; climate change; expansion

\section{Introduction}

Considering the prospects associated with the appearance of invasive species of animals on a new continent, some of the possible consequences of such actions are usually missed. It is often expected that the distribution and naturalization of invasive species can be controlled. However, this is not always possible since in open biosystems (natural and anthropogenic), in addition to human activity, the influence of changing climatic conditions takes place. However, the influence of all these negative factors in the complex can lead to the suppression of native animal species [1] and the emergence of species new to the local environment, which can actively displace not only representatives of the ichthyofauna but also the batrachofauna [2]. Therefore, the main questions that we must ask ourselves are as follows: (1) What environment is preferable (optimal) for an invasive species and in which regions are naturalization and the appearance of the species possible? (2) What consequences of this appearance could there be for native species and the environment 
in general? Of great interest is the appearance (or prospects of appearance) in temperate latitudes of thermophilic poikilothermic animals with their own strategy of viviparity, which provides them with the opportunity to reproduce even in unfavorable conditions, for example, in human-transformed territories. They also thrive and reproduce in both fresh and brackish water. Representatives of the genera Gambusia and Poecilia came to Europe as agents of a biological method for controlling the malaria mosquito at the beginning of the 20th century (they were released into the reservoirs of Western Europe). In addition, previously, they also were bred in quantities in aquarium farms as aquarium fish. Two closely related species of this genus were introduced in Europe for the above-mentioned purpose: Gambusiz affinis (Baird et Girard, 1853) and Gambusia holbrooki (Girard, 1859), but the latter species is the most widespread and occurs in Ukraine.

Gambusia holbrooki is a viviparous freshwater fish species (Poeciliidae family) originating from southern areas of North America. The species demonstrates great plasticity in the preference of comfortable water temperatures, thriving at $+31-+38^{\circ} \mathrm{C}$, but being able to survive both below and above these values [3]. This planktivorous species was used as an agent of biological control and was introduced in 1921 to the Iberian Peninsula for the first time to combat mosquito populations that played a significant role in the distribution of malaria. Later on, the fish expanded the area of its invasion to Italy in 1922 and other Mediterranean countries such as Greece, Croatia, and Spain [3]. Currently, this invasive species is well known to about 50 countries worldwide [4,5]. Besides being used for control of mosquito populations, this species is known to have negative effects on local populations of aboriginal amphibian and fish species [6,7], which makes studying its potential distribution in terms of global climate change of particular importance in order to preserve local biodiversity.

Poecilia reticulata is another viviparous freshwater fish species from North America that became invasive in Europe over recent decades. The wild form of the guppy was introduced to Europe in the 19th century. It was also used in the fight against malaria, and thus it was introduced to many places. Being popular polymorphic aquarium species, and due to their better resistance to colder water (up to $+12^{\circ} \mathrm{C}$ ), guppies became invasive as a result of many accidental releases from aquaria $[8,9]$. Their ability to store sperm for months made it possible even for a single gravid female to start a new population [10]. A wild population of guppies permanently lives in the Moskva River in the area of warm water discharge in Lyubertsy (Kuryanovsk drains) and in other places of this river [11,12]. Recently, in the Upper Volga basin, numerous self-reproducing populations of guppies have been noted in the regions of large cities (Tver, Yaroslavl, Rybinsk) in the areas of heated water discharge, as well as in settling ponds in facilities for the purification of domestic wastewater $[13,14]$. In their homeland, the island guppy populations live in brackish water and seawater, and they are bright in color and large in size. Optimal conditions for guppies include: clean water with a temperature of about $+24{ }^{\circ} \mathrm{C}$ (lives in the range of $+16-+30^{\circ} \mathrm{C}$ ), the presence of zones with vegetation and free for swimming, a varied diet with a substantial proportion of live food. There are no data on the biology of this species from the Moskva River. It is known that in the Moskva River, it reaches a high number and can be caught with a net in large numbers. For water bodies of the Upper Volga, there is an indication that it does not occur in water bodies with a temperature lower than $+17^{\circ} \mathrm{C}[14]$.

Such assumptions about the appearance and distribution of these species in Eastern Europe are most relevant in connection with their potential usage as agents of biological control against the emergence of new carriers of various diseases-blood-sucking insects [15]. Therefore, the purpose of our work was to study both climatic indicators of environmental optima for these invasive species, and the possibility of the spread of these species over Eastern Europe in space and time. 


\section{Materials and Methods}

Occurrence data were collected from original datasets [16,17], collection materials (I. I. Schmalhausen Institute of Zoology, National Academy of Sciences of Ukraine, Kyiv, Ukraine), and GBIF databases [18,19] —all non-duplicate. To account for sampling bias, we used the nearest neighbor distance ("ntbox" package in R [20]) method to thin the data, where occurrence points that were $\leq 0.1$ units away from each other were removed to avoid errors due to spatial autocorrelation. As a result, the number of points was significantly decreased: from 26,140 total points to 2278 for G. holbrooki, and to 1410 points from 4200 points for $P$. reticulata.

Ecological niche modeling and species distribution modeling (SDM) methods have been used to determine the potential home range of invasive species in new environments (MaxEnt [21] with 35 replicates, DivaGis (Bioclim)). We used bioclimatic variables from the CliMond dataset $[22,23]$. Of 35 bioclimatic variables, highly correlated $(>0.7)$ predictors were removed using the "virtualspecies" package in R, resulting in a selection of 18 for 1975 (1970-2000), 2030 (2021-2040), and 2090 (2081-2100). The area under the receiver operating characteristic (ROC) curve (AUC) was used for assessing the discriminatory capacity of the models: AUC $>0.9$ was considered excellent. GIS modeling was accomplished using SagaGis, DivaGis, and QGis [24]. Statistical processing of the obtained data was carried out using Statistica for Windows v.8.0.

\section{Results}

\subsection{Limiting Factors for P. reticulata Distribution}

As a result of GIS modeling, it was revealed that the limiting and important factors (percent contribution) for the distribution of guppies are: bio4 (temperature seasonality) at $21.9 \%$, bio3 (isothermality) at $10.6 \%$, and bio23 (radiation seasonality (C of V)) at $8.1 \%$. Annual mean temperature (bio1) has an optimum of $+14-+28{ }^{\circ} \mathrm{C}$ (marked in green, Figure 1a). In this "ecological envelope", $68.1 \%$ of the guppies are found in the temperature range of $+10-+28^{\circ} \mathrm{C}$ (Figure 1a, DivaGis, Bioclim). The temperature of $+10^{\circ} \mathrm{C}$ may have appeared as a result of extrapolation to northern areas, where warm drains are located (in large cities, etc.). According to our observations of "wild" populations of guppies in warm water bodies of the Bortnychi aeration station in Kyiv (2011-2020; 50.3837 ${ }^{\circ} \mathrm{N}, 30.6642^{\circ} \mathrm{E}$, Ukraine), these fish are quite unpretentious in terms of water quality and are generally demanding of the water temperature. The total body length in males is $1.85-3.24 \mathrm{~cm}$, and $2.00-5.50 \mathrm{~cm}$ in females. Guppies breed all year round and even in winter in warm sewage waters, and in December 2020 (water temperature $+16^{\circ} \mathrm{C}$ ), mainly juvenile individuals were registered.

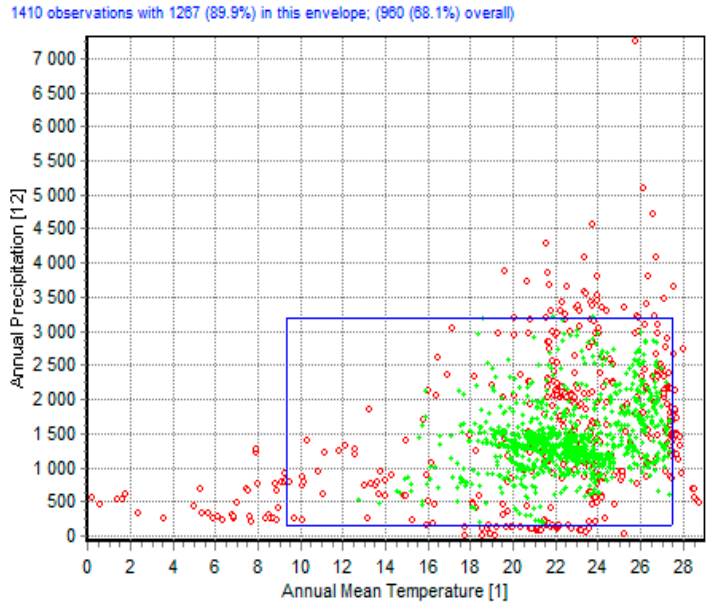

(a)

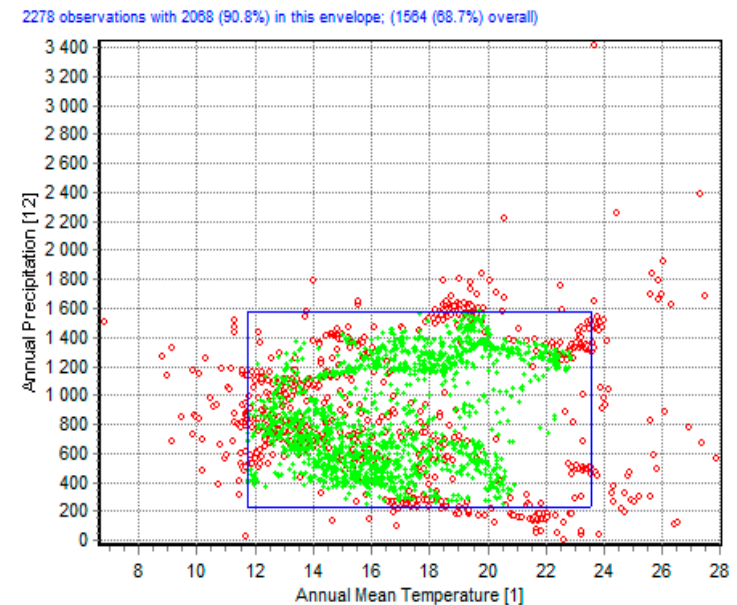

(b)

Figure 1. "Ecological envelope" (DivaGis): (a) P. reticulata; (b) G. holbrooki. 


\subsection{Limiting Factors for G. holbrooki Distribution}

On the contrary, mosquitofish can coexist in open water bodies outside the warm wastewaters of large cities and anthropogenic areas, in western and southern parts of Europe, and in Ukraine-in the Odessa region and Crimea [17]. As a result of GIS modeling, it was revealed that the most important factors (percent contribution) that limit the distribution of G. holbrooki in Europe are: bio21 (highest weekly radiation $\left(\mathrm{W} \mathrm{m}^{-2}\right)$ ) at $26.2 \%$, and bio19 (precipitation of coldest quarter $(\mathrm{mm})$ ) at $18.6 \%$. Annual mean temperature (bio1, $14.7 \%$ ) has an optimum of $+12-+23{ }^{\circ} \mathrm{C}$ (marked in green, Figure $1 \mathrm{~b}$ ). In this ecological envelope, $68.7 \%$ of $\mathrm{G}$. holbrooki finds are in the temperature range of $+11-+24{ }^{\circ} \mathrm{C}$ (Figure $1 \mathrm{~b}$, DivaGis, Bioclim). This fish is also able to reproduce throughout the year as long as the water temperature is above $+15^{\circ} \mathrm{C}$ (April-November). An interesting fact is that at a water temperature below $+10^{\circ} \mathrm{C}$, G. holbrooki burrows into the silt and falls into a suspended anabiosis. During severe winters when reservoirs are bound by ice, G. holbrooki perishes in great numbers. For instance, this species died en masse as a result of the cold winter in Sochi in 2020 [25].

Despite the fact that these American viviparous fish species are thermophilic, they occupy different ecological niches, which certainly do not coincide with native northern fish species. To compare the SDM models (Maxent, 2030 (2021-2040)) of the two species of American fish, we used the regression module in DivaGis; the resulting correlation coefficient was only 0.02. As a result of GIS modeling, climatic factors that allow new alien species to inhabit Southern Europe in the future were identified (Figures 2a,b and $3 a, b$ ).

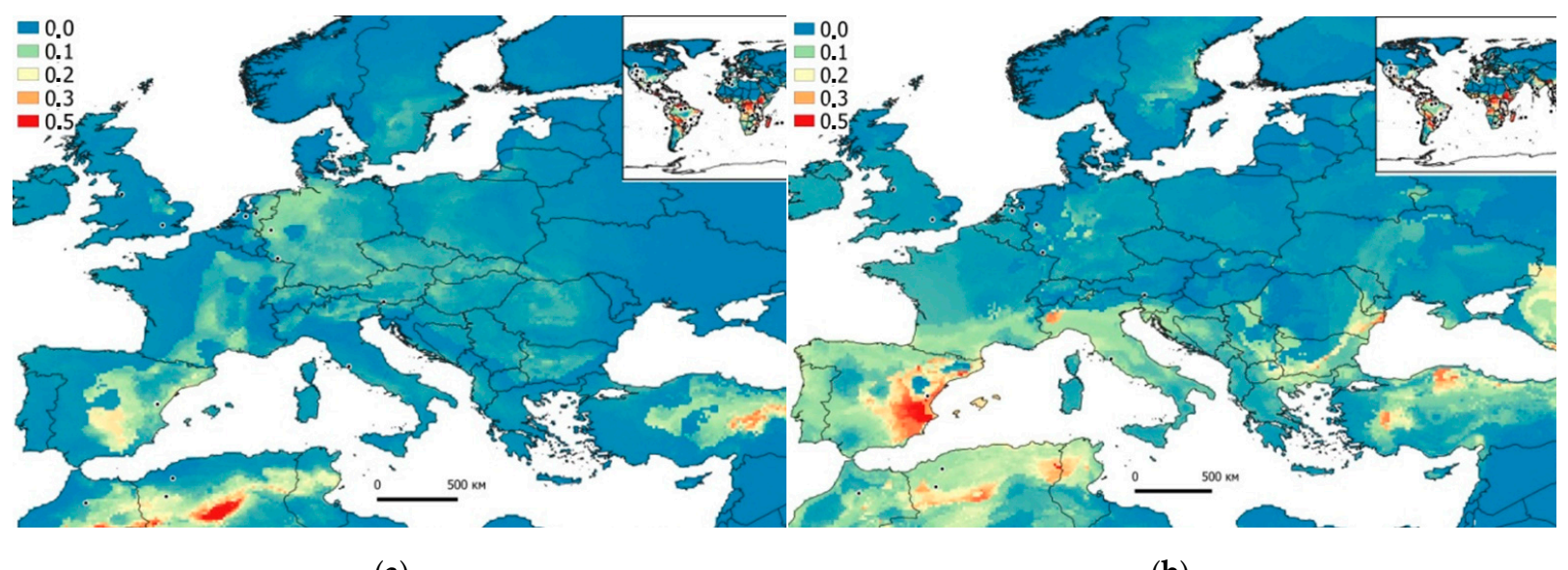

(a)

(b)

Figure 2. Potential (probabilistic) model of P. reticulata expansion built in the Maxent program based on the CliMond (a-1975 (1970-2000); b-2090 (2081-2100)) climatic data and GBIF data (2019). Areas of the highest habitat suitability $(>0.3-0.5)$ are colored in red, and areas of the lowest $(<0.1)$ are colored in blue. 


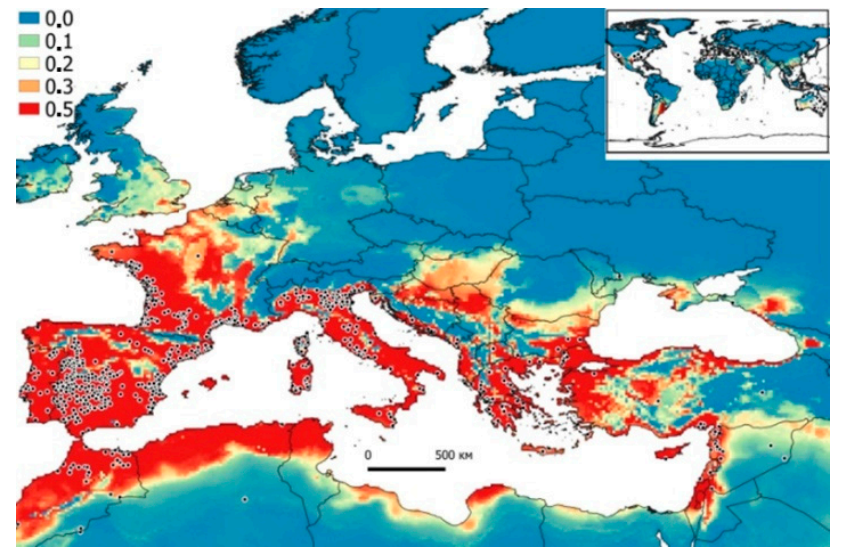

(a)

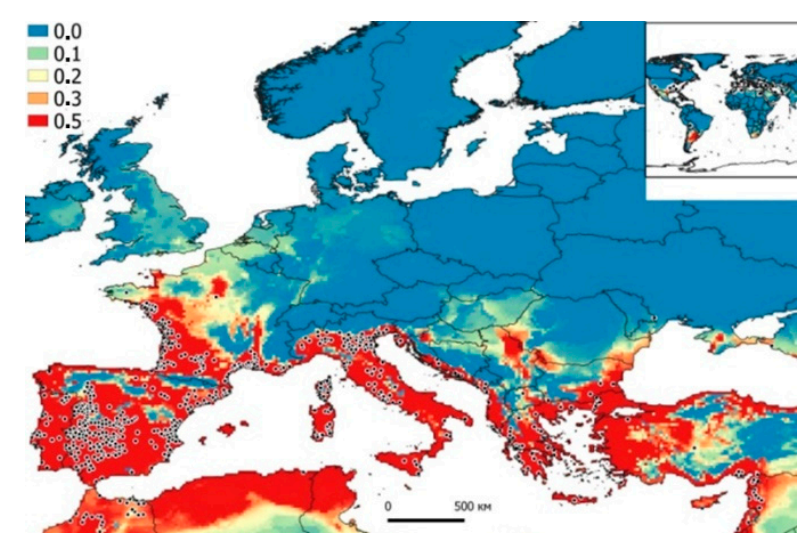

(b)

Figure 3. Potential (probabilistic) model of G. holbrooki world expansion built in the Maxent program based on the CliMond (a-1975 (1970-2000); b-2090 (2081-2100)) climatic data and GBIF data (2019). Areas of the highest habitat suitability $(>0.3-0.5)$ are colored in red, and areas of the lowest $(<0.1)$ are colored in blue.

\section{Discussion}

In our opinion, in the "warm countries" of Europe, these fish, especially mosquitofish, can pose a threat, by consuming eggs of fish and amphibians of the "Critically Endangered (CR)" yellow-spotted tree frog (see Litoria castanea in the IUCN Red List of Threatened Species), the "Endangered (EN)" green and gold frog (see Litoria raniformis in the IUCN Red List of Threatened Species), and the "Vulnerable (VU)" golden bell frog (see Litoria aurea in the IUCN Red List of Threatened Species) in Australia (NSW National Parks and Wildlife Service, 2004 [26]). In the more northern regions of Eastern Europe, in a changing climate, such thermophilic fish species do not compete with the native ichthyofauna, but they can occupy their niche in new habitats, playing an important role in ecosystems and for biological control (especially in anthropogenic areas) in a changing climate.

As a result of GIS modeling of the collected data, it was found that by 2090 (2081-2100, Figure $2 b$ ), the appearance of guppies in the south of Ukraine is possible (the estuary of the Danube River, as well as in several places in the Caucasus, Turkey, and lower part of the Don River (>0.3-0.5, Figure 3b)). G. holbrooki will also slightly expand its range in Europe, as well as in Ukraine, namely, in the Crimean Peninsula, the western part of the Black Sea region, and the Danube estuary (Figure $3 b$ ).

Author Contributions: Conceptualization, O.N., M.P., and V.T.; data curation, O.N., M.P., A.S., and A.Č.; formal analysis, O.N. V.T., and O.M.; funding acquisition, M.P., A.S., and A.Č.; investigation, O.N., M.P., O.M., and A.Č.; methodology, O.N., and V.T.; project administration, A.S., O.N., A.Č., and M.P.; resources, O.N., M.P., and AČ; software, O.N., and V.T.; supervision, O.N., V.T., and M.P.; validation, O.N., V.T., A.Č., and M.P.; visualization, O.N., V.T., and M.P.; writing-original draft and writing-review and editing, O.N., V.T., M.P., A.Č., O.M., and A.S. All authors have read and agreed to the published version of the manuscript.

Institutional Review Board Statement: Not applicable.

Data Availability Statement: The data presented in this study are openly available in Gambusia holbrooki Girard, 1859 in GBIF Secretariat (2021); GBIF.org (2 April 2021) GBIF Occurrence Download at https:/ / doi.org/10.15468/dl.d5e6w9, accessed on 2 April 2021, reference number [23], and Poecilia reticulata Peters, 1859 in GBIF Secretariat (2021); GBIF.org (16 June 2021) GBIF Occurrence Download at https:/ / doi.org/10.15468/dl.tuwazq, accessed on 16 June 2021, reference number [24].

Acknowledgments: This research was partly supported by the project "Pond aquaculture production and ecosystem service innovative research with modeling of the climate impact to tackle horizontal challenges and improve aquaculture sustainability governance in Latvia" (lzp-2020/2-0070) financed by Fundamental and Applied Research Projects (FLPP). 


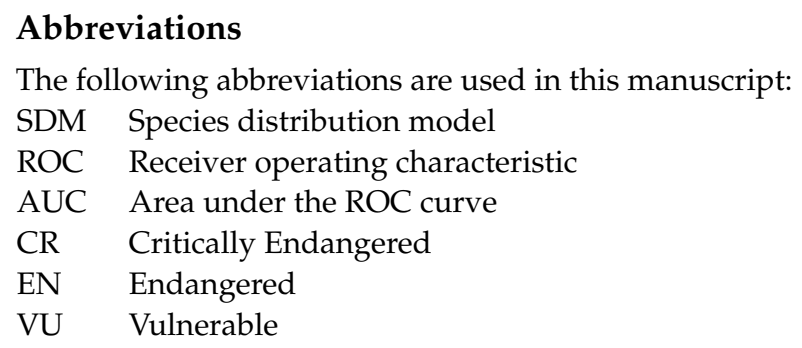

\section{References}

1. Kuybida, V.V.; Nekrasova, O.D.; Kutsokon, Y.K.; Lopatynska, V.V. Summer fish kills in the Kaniv Reservoir. Hydrobiol. J. 2019, 55, 103-106. [CrossRef]

2. Pupina, A.; Pupins, M.; Nekrasova, O.; Tytar, V.; Kozynenko, I.; Marushchak, O. Species distribution modelling: Bombina bombina (Linnaeus, 1761) and its important invasive threat Perccottus glenii (Dybowski, 1877) in Latvia under global climate change. J. Environ. Res. Eng. Manag. 2018, 74, 79-86. [CrossRef]

3. Krumholz, L.A. Reproduction in the western mosquitofish, Gambusia affinis affinis (Baird \& Girard), and its use in mosquito control. Ecol. Monogr. 1948, 18, 1-43.

4. García-Berthou, E.; Alcaraz, C.; Pou-Rovira, Q.; Zamora, L.; Coenders, G.; Feo, C. Introduction pathways and establishment rates of invasive aquatic species in Europe. Can. J. Fish. Aquat. Sci. 2005, 62, 453-463. [CrossRef]

5. Vidal, O.; García-Berthou, E.; Tedesco, P.A.; Garcia-Marin, J.-L. Origin and genetic diversity of mosquitofish (Gambusia holbrooki) introduced to Europe. Biol. Invasions 2010, 12, 841-851. [CrossRef]

6. Kats, L.B.; Ferrer, R.P. Alien predators and amphibian declines: Review of two decades of science and the transition to conservation. Divers. Distrib. 2003, 9, 99-110. [CrossRef]

7. Alcaraz, C.; Bisazza, A.; García-Berthou, E. Salinity mediates the competitive interactions between invasive mosquitofish and an endangered fish. Oecologia 2008, 155, 205-213. [CrossRef] [PubMed]

8. Padilla, D.K.; Williams, S.L. Beyond ballast water: Aquarium and ornamental trades as sources of invasive species in aquatic ecosystems. Front. Ecol. Environ. 2004, 2, 131-138. [CrossRef]

9. Strecker, A.L.; Campbell, P.M.; Olden, J.D. The aquarium trade as an invasion pathway in the Pacific Northwest. Fisheries 2011, 36, 74-85. [CrossRef]

10. Evans, J.P.; Magurran, A.E. Multiple benefits of multiple mating in guppies. Proc. Natl. Acad. Sci. USA 2000, 97, 10074-10076. [CrossRef]

11. Sokolov, L.I.; Sokolova, E.L.; Pegasov, V.A. Ichthyofauna of Moskva river within the city of Moscow and some data on its condition. Quest. Ichthyol. 1994, 34, 634-641. (In Russian)

12. Reshetnikov, Y.S.; Bogutskaya, N.G.; Vasiljeva, E.D. List of fish-like animals and fish of fresh water of Russia. Quest. Ichthyol. 1997, 37, 723-771. (In Russian)

13. Slynko, Y.V.; Kyiashko, V.N.; Yakovlev, V.N. List of Fish-Like Animals and Fish of Volga River Basin. In Catalogue of Plants and Animals of Volga River Basin; ИБВВ РАН: Yaroslavl, Russia, 2000; pp. 252-277. (In Russian)

14. Yakovlev, V.N.; Slynko, Y.V.; Kyiashko, V.N. Annotated list of Cyclostomata and Fish of water bodies of Upper Volga. In Ecological problems of Upper Volga; ИБВВ РАН: Yaroslavl, Russia, 2001; pp. 52-69. (In Russian)

15. Kozynenko, I.I.; Tytar, V.M. Bioclimatic modeling of the European distribution of the invasive Asian tiger mosquito, Aedes (Stegomyia) albopictus (Skuse, 1895), with special reference to Ukraine. Rep. Nat. Acad. Sc. Ukr. 2020, 3, 88-93. [CrossRef]

16. Kutsokon, Y.; Nekrasova, O.; Shkamerda, V.; Loparev, S. The spread of guppy (Poecilia reticulata Peters, 1859) in the Bortnychi aeration station channel of Kyiv City. In Biodiversity Dynamics 2012: In the Abstract of Scientific Materials; Zagorodniuk, I., Ed.; DZ-Taras Shevchenko LNU: Lugansk, Ukraine, 2012; pp. 94-95. (In Russian)

17. Kvach, Y.; Kutsokon, Y. The non-indigenous fishes in the fauna of Ukraine: A potentia ad actum. Bioinvasions Record 2017, 6, 269-279. [CrossRef]

18. Gambusia holbrooki Girard, 1859 in GBIF Secretariat (2021). GBIF.org (2 April 2021) GBIF Occurrence Download. Available online: https: / / doi.org/10.15468/dl.d5e6w9 (accessed on 2 April 2021).

19. Poecilia reticulata Peters, 1859 in GBIF Secretariat (2021). GBIF.org (16 June 2021) GBIF Occurrence Download. Available online: https: / / doi.org/10.15468/dl.tuwazq (accessed on 16 June 2021).

20. Osorio-Olvera, L.; Lira-Noriega, A.; Soberón, J.; Peterson, A.T.; Falconi, M.; Contreras-Díaz, R.G. ntbox: An r package with graphical user interface for modelling and evaluating multidimensional ecological niches. Methods Ecol. Evol. 2020, 11, 1199-1206. [CrossRef]

21. Phillips, S.J. A brief tutorial on Maxent. ATET Res. 2005, 190, 231-259.

22. Kriticos, D.J.; Jarošik, V.; Ota, N. Extending the suite of Bioclim variables: A proposed registry system and case study using principal components analysis. Methods Ecol. Evol. 2014. [CrossRef]

23. CliMond. Available online: https:/ /www.climond.org/ (accessed on 27 December 2020). 
24. Nekrasova, O.D.; Tytar, V.M.; Kuybida, V.V. GIS Modeling of Climate Change Vulnerability of Amphibians and Reptiles in Ukraine; NAS of Ukraine, Shmalgausen Institute of Zoology NAS: Kyiv, Ukraine, 2019; 204p, ISBN 978-966-02-8956-7. (In Ukrainian)

25. National Geographic Russia. Available online: https://nat-geo.ru/nature/v-sochi-ozhidayut-nashestviya-malyarijnyhkomaroviz-za-massovoj-gibeli-ryby-gambuzii/ (accessed on 11 June 2020).

26. Global Invasive Species Database: Gambusia Holbrooki. Available online: http://issg.org/database/species/ecology.asp?si=61 $7 \& \mathrm{fr}=1 \&$ sts $=$ sss\&lang $=\mathrm{EN}$ (accessed on 11 June 2020). 